\title{
ECONOMY
}

\section{THE ROLE OF ECONOMIC RELATIONS WITH POLAND IN THE INTEGRATION OF AZERBAIJAN INTO THE WEST}

\author{
Toghrul Allahmanli \\ Odlar Yurdu University, Azerbaijan \\ Lodz University, Poland
}

DOI: https://doi.org/10.31435/rsglobal_wos/30112019/6807

\section{ARTICLE INFO \\ KEYWORDS \\ Azerbaijan's economy, \\ Polish economy, \\ field structure, \\ economic relations, \\ import, export.}

Received: 10 September 2019

Accepted: 19 November 2019

Published: 30 November 2019

\begin{abstract}
Analysis of perspective directions of economic relations between Azerbaijan and Poland as a problem is characterized by rich facts. Because it clarifies the importance and prospects of joint use of both Azerbaijan and Poland's economic opportunities, joint use of natural resources, labor, modern technology. Historical perspectives and developmental characteristics of the field structure economics allow for rich analysis and characterize a substantial fact in the context of the processes in the economy of Europe and Asia in general. Poland, which has a large potential in terms of territory and population in Europe, plays a key role as an important economic partner for Azerbaijan.
\end{abstract}

Citation: Toghrul Allahmanli. (2019) The Role of Economic Relations with Poland in the Integration of Azerbaijan into the West. International Academy Journal Web of Scholar. 11(41), Vol.2. doi: 10.31435/rsglobal_wos/30112019/6807

Copyright: (C) 2019 Toghrul Allahmanli. This is an open-access article distributed under the terms of the Creative Commons Attribution License (CC BY). The use, distribution or reproduction in other forums is permitted, provided the original author(s) or licensor are credited and that the original publication in this journal is cited, in accordance with accepted academic practice. No use, distribution or reproduction is permitted which does not comply with these terms.

Introduction. The Republic of Poland is selected by the advantages of a number of areas in Central Europe, for example, the service area, the potential of domestic markets and the importance of economic relations. The success rate of the republic's geographical position is also of great importance. Poland is border with Germany in the west, the Czech Republic and Slovakia in the south, Ukraine and Belarus in the east, the Baltic Sea, Lithuania and Russia in the north are one of the factors that show that Poland's foreign trade turnover is rich. The country also has sea borders with Denmark and Sweden, which implies the fertility of foreign economic relations. All this is an indication of the fact that Poland is represented by a substantial fact in building economic relations.

Looking at the general geographical conditions of Azerbaijan, the features of accommodation, there is a perspective on perspective. Thus, the Republic of Azerbaijan is selected by the wealthiest resources of the South Caucasus as a state in the Caspian basin. Its economic potential, favorable characteristic for geo-economic conditions, as well as the interest of East, West, North and South as a transit country are important in the economic view of the 21 st century. From the north to Russia, Georgia, and from the west to Armenia, Turkey and south to Iran, promises successful prospects in geo-economic processes. It should be noted that the Nakhchivan Autonomous Republic, which is the Azerbaijani enclave, borders with Armenia northeast, Iran and the West, and north-west of Turkey. It is a substantial factor in the trade relations of the Caspian basin countries. Therefore, these two countries are calculated with the same features as the differences in renewable and non-renewable resources, as well as the uniqueness of geographical conditions. 
Issue overview. Azerbaijan is a successful partner in the South Caucasus, with its economic potential, the richness of the restored and non-existent economy, and the dynamics of representation in the foreign market. As for the Asian country (in terms of the border between Europe and Asia), the prospects of Azerbaijan's economic relations with Poland, or rather a central European country, provide a solid basis for typological analysis with other countries. At the same time, it will help to identify the perspective of the issue and to clarify its strategic targets.

Analysis of relations between Azerbaijan and Poland in economic matters necessitates the clarification of the history of political and cultural relations. Of course, the information provided by historical sources, scientific literature, and press organs determines the abundance of rich facts. From the beginning of the 19th century, interest of science, culture, creative environment, geographers to the Caucasus as well as its part of Azerbaijan has always been increasing. Architectural monuments, as well as Polish ethnographers, archaeologists, historians, literary critics and musicians are all clarified. For example, translations of the Polish orientalist Josef Sepkovsky, articles on Baku and its architecture (1825), the first edition of Koroghlu epos as a book (1842, Alexander Hodzko) and others are the indications of these links to Azerbaijan. Necessary work of the Polish Oriental Studies School about Azerbaijan today has a specific weight for its masquerade and degree of its value. The course of events in the Soviet era is another line, in other words, in the territorial union of the Soviet Union of Azerbaijan, Poland was interconnected in the socialist countries. Therefore, the development of the general picture of these two countries after the collapse of the Soviet Union, the level of development is characterized by a substantial peculiarity, fact richness as a problem.

Solution of issue. Analysis of the economic potential of Azerbaijan as a country of the Caspian basin at the level of geo-economic relations with another Central European country, Poland, contributes to revealing the genetics of globalization in modern conditions, what is happening in its inner-technological sphere and what content is characteristic. Investigating the issue of international economic relations in the vicinity of climatic conditions, but in the context of different political systems, makes it necessary to clarify the points of contact in the global economic sphere, the development of the economic processes, and to highlight the prospective world targets. The speed of modern technological development has diminished the world, and the necessity, the economic, cultural links between the countries, has been inevitable. Comparative economic analysis of Central Europe, which has rich sources of resources in the Caspian basin and the Black Sea, more precisely, with the view of economic processes and the advantages of the field of service, defines the development perspective of geo-economic relations. Importance and export relationships, clarity of production targets, and the proper formulation of market relations, as a whole, need to be mutually beneficial to the dynamics of relationships and the improvement of living standards. They depend on the accuracy and success of economic diplomacy in one direction. One of the important principles in the regulation of economic diplomacy is the provision of state sovereignty over natural resources and economic activity. This principle includes the following:

- Wealth, ownership, disposal, use and independent economic activity of the state;

- Control over economic activity in the relevant sphere;

- Free detection of natural resource utilization;

- Nationalization of foreign capital for public, state interests in accordance with international law;

- Unite in the organization of natural resource providers;

- Compensation of damages caused by restoration of control over natural resources and occupied territories due to temporary loss of natural resources and sovereignty.

It is the principle of economic cooperation, which has a special role in the regulation of international economic relations. Apparently, these provisions in the context of economic-diplomatic relations include a conceptual view, those related to natural resource and economic activity. Here is a point in the context of the Republic of Azerbaijan related to the economic activity in the occupied territories.

Azerbaijan and the Republic of Poland are closer to the ancient, medieval times with its history, statehood tradition. According to historical sources, the first Polish state belongs to the $\mathrm{X}$ century (966) and its borders coincide with the borders of today's Polish Republic. In 1025, the kingdom became a kingdom, uniting with the Lithuanian Duchy in 1569 and founded the PolishLithuanian unity and collapsed in 1795. Poland gained its independence in 1918 and was again occupied by the Second World War. After the defeat of the Germans, the Soviet Union was under control and re-gained independence after the regime's collapse (1989). This structure is characterized by modern history studies in the history of Poland as the name of "third republic".

Poland is a member of the European Union, NATO, the UN, the Economic Cooperation Organization, and the World Trade Organization. It is the sixth largest population in the European 
Union. Poland, a liberal democratic country consisting of sixteen-year-olds, has a special significance as its partner with all economic indicators.

The policy of opening the West is a new milestone in the history of Poland. The independence of Azerbaijan and Poland at the same time has made the reforms in the economy and the implementation of systematic economic policies. Both Azerbaijan and Poland have embarked on a path of successful development and have solved most of the post-independence problems. International Development Association, International Finance Corporation, International Labor Organization, International Monetary Fund, Labor and Agriculture Fund, World Trade Organization and other, representation of organizations and establishing a workable perspective.

There are enough fundamental researches on the history of the Azerbaijan Republic, rich cultural fund of the people, statehood traditions. It is one of the oldest living and cultural centers in the world. Azikh caves, Kuruchay culture, Damcilı and other, characterized by serious archeological facts. Ethnographers, historians, musicians and others, interests and monographs are examples. The history of statehood is measured in millenniums. All this is characterized by the fact that economic parallels at the level of Azerbaijan and Poland are followed by the processes taking place in the economy of the last period.

The Polish industry is characterized by varied diversity. Shipbuilding, forestry, textile, chemistry, metal industry, aluminum, oil products are characterized by successful development. Dada is very much represented in the foreign market with the mining and mining industries. It should be added that Poland is the most coal producer in Europe after Germany and England. Salt, iron, manganese and so on, have a specific weight during the summer. In recent years, the most successful is the development of the paper industry.

Pay attention to concentration processes in the Polish food industry. In 2010, more than 250 employees, representing only $1.7 \%$ of approximately 16,000 companies operating in the sector, accounted for $36.9 \%$ of all employment and $54.1 \%$ of production value. Three capital groups account for $85.7 \%$ of oil production, $78.5 \%$ for beer production, $76.9 \%$ for tobacco industry, $75.6 \%$ for potato production and $69.6 \%$ for sugar. In 2003-2010, production cost increased from 102.7 to 158.9 billion PLN, while the number of enterprises decreased from 19.52 to 15.97 thousand. In 2013, the concentration in sales was 0.79 per cent in food production, 0.66 in beverage production and 0.37 in the tobacco industry. It is also expected that the concentration process in the food sector will continue and the role of large companies will increase. ${ }^{1}$

A significant increase in the production value of companies analyzed during the 2002-2013 period in the food sector in Poland is observed. In 2013, the maximum was 212.93 million PLN and $127.22 \%$ more than in 2002. It should be noted that in 1995-2013 all Poland agro-food sector exported from 3 billion euros to 14 billion euros, for example in 2012 almost 77 percent came to the EU markets. ${ }^{2}$

Energy production in the Polish economy has a specific weight. Even in the energy-rich countries, Poland is specifically mentioned. Gdansk and Selanga ports play an important role in ensuring the economic viability of the country. Local food, aluminum and artificial fibers have specific weight for industry development and profitability. As it is known, the transformation of the economy into three directions:

- Systematic approach to the formation of income as the basis of society and economy liberalization;

- Systematic restructuring of the attitude towards capital formation and activity as a basis of the market economy;

- Reorganization of management, economy - institutional structure, market requirements.

Of course, both Poland and Azerbaijan have made significant progress in liberalizing society and the economy.

The British economist D. Ricardo, who lived in the late XVIII century and at the beginning of the nineteenth century, emphasized that "foreign trade increases the amount and diversity of objects that can be profitable in the future, although it is very profitable for a country and promotes wealth and

\footnotetext{
${ }^{1}$ Justyna Kufel, Institute of Agricultural and Food Economics - National Research Institute, Poland, Monopolistic Markups in the Polish, Proceedings of the 8th International Conference on Applied Economics Contemporary Issues in Economy under the title Market or Government?. Torun, Poland: Institute of Economic Research and Polish Economic Society Branch in Toruń, 18-19 June 2015, p.1012

2 Justyna Kufel, Institute of Agricultural and Food Economics - National Research Institute, Poland, Monopolistic Markups in the Polish, Proceedings of the 8th International Conference on Applied Economics Contemporary Issues in Economy under the title Market or Government?. Torun, Poland: Institute of Economic Research and Polish Economic Society Branch in Toruń, 18-19 June 2015, p.1025
} 
cheapness of goods, when the commodity imports are different from the wages paid, there is no tendency to increase profits.

Nevertheless, there is no increase in the productivity of vehicles with better inventiveness through the creation of roads or channels, or by reducing the ability to work in the production or delivery of goods. " This judgment is based on a serious invoice in the way of economic relations. Correctness of the international economic relations is essential for the solution of the economic problems of the countries that have left the socialist system and the improvement of the success rate.

Poland recognized Azerbaijan's independence on December 27, 1991, and diplomatic relations between the two countries were established on February 21, 1992. Poland was established in 2001 and Azerbaijan's embassy in Poland was established in 2004. Significant progress has been made in recent years between Azerbaijan and Poland in economic and trade relations. ${ }^{2}$ Oil and oil products dominate the products exported from Azerbaijan. Great prospects are also expected in energy cooperation. This shows that the importance of Azerbaijan in the energy security of Poland will increase in the coming years.

When paying attention to statistical indicators of recent times, it is clear that Poland's industry is characterized by high indicators and is of interest to diversity. Mechanical engineering, chemical industry, agrarian industry, metallurgy, forestry and others. The growth in the field is an example of this. In addition, the production of furniture, construction materials and construction has a specific weight. Light and heavy industry, chemical industry, shipbuilding, metal car, aircraft, machinery, cement, aluminum are major industrial aspects. Recently, woodworking and paper industries, textiles and forestry have a special role in the country's economic life. The mining and mining industries are quite developed. The most important of these are coal, zinc and copper. The efficiency of the underground resources also constitutes a serious partner of Poland in international economic relations. All this gives rise to the success of foreign economic relations, geo-economic relations between Poland and Azerbaijan. As is known, Europe has a geoeconomic space as a diversity of economic indicators and its economic potential. Therefore, in terms of strength and potential, these countries are also governed by different economic relations. For example, the Eurozone countries have more favorable advantages. In the EU countries, economic stability is seen as a special case. This is reflected in the European Commission's report.

Conclusions. After gaining independence, Azerbaijan preferred to build business on the basis of mutual economic cooperation with the various developed countries of the world. The interest in attracting international power centers, as well as economic entities, as a party to economic agreements, was the basis for prospects. Relationships with Europe and the East, as well as with the South Caucasus countries, have created the necessary conditions for the solution of economic needs. Cooperation with the Republic of Poland, meeting of presidents, signing of state-level agreements, signing of economic projects, trade relations determine the importance and prospects of foreign economic relations. Features of the economy of Azerbaijan and Poland, tendencies of development, field structure and so on, which creates necessary conditions for their connections. All this gives rise to a general view of the economic opportunities of the Polish and Azerbaijani Republics, and the broad base of mutual economic relations.

\section{REFERENCES}

1. Jadvyga Ciburiene, Kaunas University of Technology, Lithuania, The Evaluation of Economic Development, Proceedings of the 8th International Conference on Applied Economics Contemporary Issues in Economy under the title Market or Government? Torun, Poland: Institute of Economic Research and Polish Economic Society Branch in Toruń, 18-19 June 2015

2. Justyna Kufel, Institute of Agricultural and Food Economics - National Research Institute, Poland, Monopolistic Markups in the Polish, Proceedings of the 8th International Conference on Applied Economics Contemporary Issues in Economy under the title Market or Government? Torun, Poland: Institute of Economic Research and Polish Economic Society Branch in Toruń, 18-19 June 2015

3. Rikardo D. On the principle of political economy and taxation. Canada, Ontario, Kitchener, 2001

4. Węcławowicz Gregorz. Contemporary Poland: Space and Society. Boulder, CO: Westview Press, 1996

5. Chodubski, Andrzej, Azerbejdżan-Polska: odsłony kontaktów kulturowych. Poland: Wydawnictwo Adam Marszałek, 2015

6. http://www.today.az/print/news/politics/109576.html

7. state.gov.pl

8. state.gov.az

\footnotetext{
${ }^{1}$ Ricardo D. On the principle of political economy and taxation. Canada, Ontario, Kitchener, 2001. p.89

${ }^{2} \mathrm{http} / / / \mathrm{www}$. today.az/print/news/politics/109576.html
} 